\title{
Implementasi Model Proyeksi Simple Time Series: Pelatihan Untuk Perencana Pembangunan Daerah
}

\author{
Mohtar Rasyid \\ Fakultas Ekonomi dan Bisnis Universitas Trunojoyo Madura \\ E-mail : mohtar.rasyid@trunojoyo.ac.id \\ DOI: https://doi.org/10.21107/pangabdhi.v6i1.6929 \\ Naskah diterima 2 Februari 2020, Revisi 30 Maret 2020, Terbit 19 April 2020
}

\begin{abstract}
Abstrak
Perencanaan daerah menjadi salah satu elemen penting pembangunan daerah. Terkait dengan hal tersebut, Bappenas serta Fakultas Ekonomi dan Bisnis UTM menyelenggarakan pelatihan perencanaan pembangunan daerah bagi aparat perencana daerah. Tujuan dari artikel ini adalah untuk mendeskripsikan kegiatan pelatihan yang meliputi bahan kajian, metode penyampaian serta evaluasi hasil pelatihan. Metode penyajian di desain dengan pendekatan before-after treatment evaluation. Sebelum dilakukan pelatihan, terlebih dahulu dilakukan simulasi perhitungan data oleh peserta yang diukur waktunya oleh narasumber dan tim. Setelah dilakukan pelatihan, peserta diwajibkan untuk mengerjakan tugas dengan data riil pembangunan. Hasil evaluasi menunjukkan bahwa lebih dari separuh (75\%) peserta dapat mengerjakan tes dalam waktu yang lebih cepat. Diantara 25\% peserta yang masih kesulitan mengerjakan tes dalam waktu lebih cepat mengakui bahwa belum pernah membuat analisis kuantitatif. Namun setelah diberikan toleransi perpanjangan waktu, semua peserta dapat melakukan tugas proyeksi secara tuntas. Berdasarkan hasil pelatihan ini disimpulkan bahwa pengenalan model proyeksi yang lebih sederhana terbukti efektif dalam meningkatkan kemampuan aparat dalam melakukan perencanaan daerah
\end{abstract}

Kata kunci: proyeksi, perencana, pembangunan, daerah

\begin{abstract}
Regional planning is one important element for regional development. Bappenas and Faculty of Economics and Business UTM held regional development planning training for regional planning officers. The purpose of this article is to describe training activities which include study material, delivery methods and evaluation of training results. The presentation method is designed by before-after treatment evaluation. Before the training is conducted, simulation of data calculation by the participants is first measured by the committee. After the training is conducted, participants are required to work on assignments with real development data. Results show that more than half (72\%) of participants can take the test in a faster time. Among the 28\% of participants admitted that they had never made a quantitative analysis. However, after being given an extended tolerance, all participants can complete the projection task. Based on the results of this training it was concluded that the introduction of a simpler projection model proved effective in increasing the ability of the apparatus to carry out regional planning.
\end{abstract}

Key Words : projection, planner, development, regions

\section{PENDAHULUAN}

Perencanaan pembangunan daerah merupakan elemen penting dalam mencapai kesuksesan pembangunan di daerah (Orbawati, 2002). Tanpa perencanaan yang matang, hampir dipastikan pembangunan yang dilakukan tidak akan berhasil mencapai tujuan serta visi misi yang telah ditetapkan. Sehubungan dengan hal tersebut, Badan Perencana Pembangunan Nasional (BAPPENAS) mengadakan program pendidikan dan pelatihan (Diklat) perencanaan pembangunan daerah untuk menyusun dokumen Rencana Pembangunan Jangka Menengah Daerah (RPJMD).

Salah satu mitra BAPPENAS dalam program tersebut adalah Fakultas Ekonomi dan Bisnis Universitas Trunojoyo Madura (UTM) sebagai tindak lanjut kerja sama Rektor UTM dengan pihak BAPPENAS. Kegiatan ini sudah berlangsung sejak tahun 2015 dan hingga tahun 2019 telah memasuki angkatan VI. Peserta Diklat RPJMD adalah utusan dari berbagai aparat 
perencana pembangunan daerah dari beberapa Badan Perencana Daerah (Bappeda) level kabupaten/kota maupun tingkat provinsi di seluruh Indonesia.

Pemateri Diklat ini secara umum terdiri dari tiga unsur. Pertama, akademisi perencana pembangunan daerah yang sebagian besar adalah dosen dari FEB-UTM yang memiliki pengalaman sebagai narasumber dalam penyusunan dokumen perencanaan daerah. Kedua, ahli perencanaan pembangunan daerah atau nasional yang merupakan utusan dari Bappenas, Jakarta. Adapun unsur yang ketiga adalah praktisi atau aparat daerah yang telah memiliki pengalaman menyusun rencana pembangunan daerah dengan cukup baik.

Materi Diklat disesuaikan dengan perkembangan peraturan terkait, masukan dari Bappenas mengenai kurikulum Diklat serta dinamika ekonomi pembangunan yang terjadi saat ini. Secara umum, materi Diklat yang disajikan antara lain: filosofi pembangunan nasional, sistem perencanaan pembangunan nasional, metode analisis data daerah, identifikasi dan analisis potensi daerah, kebijakan penganggaran, analisis dan evaluasi kinerja pengelolaan keuangan daerah serta teknik perumusan isu strategis daerah. Detail kegiatan serta materi diklat bervariasi antar angkatan, namun beberapa materi menjadi menu tetap dalam beberapa diklat. Salah satu materi yang tetap dipertahankan adalah yang berkaitan dengan metode analisis data daerah yang salah satunya membahas mengenai analisis proyeksi.

Dalam menyusun proyeksi indikator perekonomian, perencana pembangunan daerah banyak menemukan kesulitan untuk memprediksi nilai indikator penting dalam beberapa tahun mendatang. Kesulitan tersebut dialami karena banyak diantara perencana pebangunan daerah kurang terbiasa menggunakan teknik analisis kuantitatif. Halangan mental untuk mempelajari analisis kuantitatif biasanya timbul dari asumsi yang timbul bahwa analisis ini sangatlah rumit. Oleh karena itu sangat diperlukan pendekatan baru untuk membantu para perencana pembangunan daerah dalam menyusun dokumen perencanaan secara lebih komprehensif.

Beberapa teknik analisis data kuantitatif yang berhubungan dengan masalah proyeksi ekonomi pada dasarnya sudah banyak dibahas oleh beberapa penulis. Teknik yang paling sederhana antara lain menggunakan trend data runtun waktu secara linear (Badan Pusat Statistik, 2010).
Beberapa teknik yang lebih modern tidak hanya menggunakan persamaan tunggal, namun telah mendesain persamaan sistem untuk melakukan peramalan yang lebih mendalam (Saputra et.al., 2012).

Dalam konteks yang lebih rumit lagi, pendekatan proyeksi bisa dilakukan untuk mengestimasi pola hubungan jangka panjang antar lebih dari dua variabel (Putra dan Meydiawati, 2017). Penelusuran yang lebih panjang mengenai sejarah perkembangan teknik peramalan kuantitatif menggunakan data ekonomi makro dapat dilihat dalam beberapa literatur (Rasyid, 2015).

Pengenalan metode proyeksi secara komprehensif kepada peserta Diklat sepanjang pengalaman pelatihan pada angkatan sebelumnya, hanya menyisakan rasa kepenatan dan mengurangi motivasi untuk mempelajari teknik proyeksi secara tuntas. Padahal tujuan utama dari pelatihan adalah diharapkan peserta mampu mengembangkan budaya penyusunan kebijakan berbasis evidence (Adriansyah et.al., 2019). Jika penerimaan awal peserta terhadap materi sudah kurang bagus, selanjutnya akan berdampak kurang baik.

Untuk itulah dalam Diklat angkatan ke VI dipilih materi proyeksi data ekonomi yang memiliki kriteria sebagai berikut:

1. Mudah difahami

2. Menggunakan data riil perencanaan

3. Mudah dipraktekkan

4. Menggunakan alat atau software populer

5. Pernah digunakan dalam penyusunan dokumen perencanaan.

Untuk menindaklanjuti rincian permintaan sebagaimana tersebut diatas maka dilakukan beberapa langkah pendahuluan. Pertama, penyelenggara diklat dengan masukan dari narasumber mencari contoh dokumen perencanaan yang dinilai cukup baik dalam menggunakan aplikasi proyeksi. Kedua, menelusuri beberapa teknik proyeksi dari metode yang sederhana sampai yang paling sederhana. Ketiga, menguji-cobakan metode tersebut terhadap beberapa mahasiswa secara acak, sebelum nantinya betul-betul digunakan untuk bahan pelatihan terhadap peserta Diklat RPJMD.

Penelusuran awal dari kegiatan diatas menghasilkan beberapa hal sebagai berikut. Pertama, Dokumen RPJMD yang digunakan sebagai bahan acuan adalah Dokumen RPJMD Kota Bandung yang dianggap cukup representatif. Kedua, teknik analisis proyeksi yang dipilih adalah Model Simple Time Series 
dengan penggunaan data tahunan selama lima tahun ke belakang (sesuai dengan umur dokumen perencanaan). Terakhir, setelah diuji cobakan kepada mahasiswa semester awal, metode yang dipilih relatif mudah difahami bahkan oleh mahasiswa yang belum menempuh mata kuliah metode analisis kuantitatif seperti statistika dan matematika ekonomi sekalipun.

\section{METODE}

Diklat RPJMD angkatan VI dilaksanakan di Gedung RKB Fakultas Ekonomi dan Bisnis Universitas Trunojoyo Madura. Peserta diklat terdiri dari para aparat perencana daerah yang berasal dari Bappeda kota/kabupaten di Jawa Timur serta beberapa daerah lain luar Jawa Timur.

Materi yang disajikan dalam Diklat ini adalah model simple time series yang dimodifikasi dari model analisis regresi. Modifikasi model ini dikonstruksi dengan menyusun asumsi ketat sebagai berikut.

1. Data yang digunakan untuk perhitungan adalah lima tahun ke belakang.

2. Asumsi pertumbuhan data adalah linear dengan deviasi yang minimum.

3. Jenis data yang bisa digunakan bersifat stok, seperti PDRB, Jumlah Penduduk dan Angkatan Kerja.

Model dasar proyeksi sederhana dapat dinyatakan sebagai berikut:

$$
Y=\alpha+\beta X+e .
$$

Dalam hal ini $\mathrm{Y}$ adalah variabel yang akan diproyeksikan dan $\mathrm{X}$ adalah variabel prediktor yang untuk tujuan prediksi bisa menggunakan variabel waktu. Secara teori, untuk memperoleh nilai proyeksi maka terlebih dahulu harus mendapatkan estimasi koefisien $\alpha$ dan $\beta$. Rumus untuk memperoleh estimasi koefisien $\alpha$ adalah:

$$
\alpha=\mathrm{A}: \mathrm{B}
$$

dimana :

$$
\begin{gathered}
\mathrm{A}=\Sigma \mathrm{Y}\left(\Sigma \mathrm{X}^{2}\right)-\Sigma \mathrm{X} \Sigma \mathrm{Y} . \\
\mathrm{B}=\mathrm{n} \Sigma \mathrm{X}^{2}-(\Sigma \mathrm{X})^{2} \ldots \ldots \ldots \ldots
\end{gathered}
$$

Sedangkan untuk memproleh estimasi koefisien $\beta$ dilakukan menggunakan rumus sebagai berikut:

$$
\begin{aligned}
\beta & =\mathrm{C}: \mathrm{D} \ldots \ldots \ldots \ldots \ldots \\
\mathrm{C} & =\mathrm{n} \Sigma \mathrm{Y}-\Sigma \mathrm{X} \Sigma \mathrm{Y} . \\
\mathrm{D} & =\mathrm{n} \Sigma \mathrm{X}^{2}-(\Sigma \mathrm{X})^{2} .
\end{aligned}
$$

Setidaknya dibutuhkan enam langkah formula untuk memperoleh model estimasi proyeksi untuk model (1). Dengan proses yang bertahap seperti itu dapat menyebabkan peserta diklat merasa jenuh karena proses proyeksi masih belum bisa dilakanakan sebelum mengeksekusi rangkaian formula. Sebagai alternatif, diajukan formula sebagai berikut:

$$
\alpha=\text { rata-rata } Y \text {. }
$$

$\beta=(\mathrm{d} 5 * 2+\mathrm{d} 4-\mathrm{d} 2-\mathrm{d} 1 * 2): 10$

Dalam hal ini d5 adalah data ke lima dan seterusnya. Teknik alternatif yang ditawarkan lebih sederhana karena hanya membutuhkan dua formula. Cara ini bisa dilakukan asal asumsi yang sebelumnya telah dipenuhi dan variabel prediktor diubah menjadi nilai numerik 1 sampai 5.Ilustrasi contoh perhitungan proyeksi model time series sederhana ini dapat diperhatikan dalam ilustrasi tabel sebagai berikut. Angka yang digunakan merupakan data riil PDRB dari daerah tertentu yang dinyatakan dalam satuan juta.

Tabel 1. Data Mentah Perhitungan Model Proyeksi Simple Time Series

\begin{tabular}{ccccc} 
No & Year & PDRB & $\begin{array}{c}\text { Ident } \\
\text { Data }\end{array}$ & $\begin{array}{c}\text { Konversi } \\
\text { T }\end{array}$ \\
\hline 1 & 2010 & 90.583 & data 1 & -2 \\
2 & 2011 & 134.436 & data 2 & -1 \\
3 & 2012 & 178.468 & data 3 & 0 \\
4 & 2013 & 248.793 & data 4 & 1 \\
5 & 2014 & 385.833 & data 5 & 2 \\
\hline
\end{tabular}

Sumber: Materi PPD-RPJMD, FEB UTM, Angkatan VI, 2019

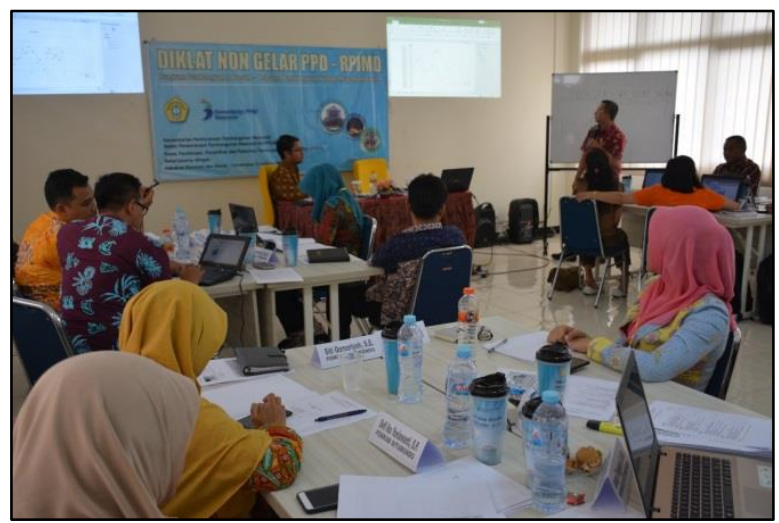

Gambar 1. Penyajian Materi Model Proyeksi Simple Time Series

Setelah materi disajikan, maka langah selanjutnya adalah melakukan evaluasi terhadap efektivitas penyajian materi. Untuk keperluan evaluasi, dilakukan beberapa tahapan sebagai berikut. Pertama, peserta diminta untuk membuat proyeksi PDRB menggunakan bahan yang disajikan dalam materi sesuai dengan standar perhitungan proyeksi. Kedua, setelah dilakukan pelatihan, peserta diminta untuk melakukan perhitungan ulang proyeksi yang dilakukan dengan menggunakan materi baru yang telah disesuaikan dengan kebutuhan pelatihan RPJMD. 
Selanjutnya dilakukan perbandingan kinerja perhitungan sebelum dan sesudah pelatihan.

\section{HASIL DAN PEMBAHASAN}

Bahan materi sebagaimana telah disinggung dalam bagian sebelumnya didistribusikan dengan dua tahap. Tahap pertama, materi proyeksi diberikan dalam modul yang dibagi secara bersamaan dengan materi lain di awal pelatihan (sebelum pelatihan). Dalam tahap ini peserta diminta untuk mengerjakan pre-test dengan materi dan bahan yang disajikan sebelumnya.

Sebelum acara pelatihan dimulai, peserta diklat diminta untuk mengerjakan tugas proyeksi dalam lembar jawaban yang disediakan secara khusus. Disamping itu, disediakan lembar evaluasi untuk menampung "keluhan" peserta diklat jika ditemukan beberapa masalah terkait dengan soal yang diberikan. Untuk evaluasi tahap pertama dilakukan penilaian kinerja awal guna menghitung tingkat pemahaman awal peserta. Hasil record dari pre-test ini dapat direkapitulasi sebagai berikut:

Tabel 2. Data Pre-Test Proyeksi

\begin{tabular}{clc}
\hline No & \multicolumn{1}{c}{ ID Peserta } & Hasil \\
\hline 1 & Bappeda 02 & 60 \\
2 & Bappeda 05 & 60 \\
3 & Pemda 01 & 60 \\
4 & Bappeda 06 & 50 \\
5 & Pemda 02 & 50 \\
6 & Dinas 12 & 50 \\
7 & Dinas 13 & 50 \\
8 & Pemda 05 & 50 \\
9 & Pemda 07 & 45 \\
10 & Bappeda 01 & 45 \\
11 & Bappeda 09 & 40 \\
12 & Bappeda 08 & 40 \\
\hline
\end{tabular}

Hasil pre-test menunjukkan bahwa keberhasilan peserta dalam mengerjakan tugas adalah sekitar $25 \%$ peserta. Selebihnya banyak peserta yang tidak bisa mengerjakan tugas dengan baik. Soal pre-test diberikan secara take home exam degan waktu pengerjaan yang lebih fleksibel. Beberapa alasan disampaikan oleh pesarta terkait dengan hasil pre-test.

Tabel 3. Informasi Pre-Test

\begin{tabular}{clc}
\hline No & Deskripsi & \% \\
\hline 1 & Soal rumit & 40 \\
2 & Waktu kurang & 25 \\
3 & Contoh minim & 10 \\
4 & Tidak paham & 8 \\
5 & Salah hitung & 5 \\
6 & Lain-lain & 12 \\
\hline
\end{tabular}

Terikat dengan hasil pre-test, beberapa argumentasi disampaikan oleh peserta antara lain: soal terlalu rumit (40\%); waktunya sangat singkat (25\%); contoh soal tidak ada atau minim $(10 \%)$; tidak faham dengan soal $(8 \%)$; salah perhitungan $(5 \%)$; serta alasan lain seperti telat mendapat soal, masih fotocopy soal, tertinggal di laptop lain, tidak bisa diprint dan lain sebagainya (12\%). Berdasarkan hasil pengamatan dan analisis terhadap argumentasi peserta, dapat disimpulkan bahwa sebagian besar peserta memang belum pernah melakukan analisis proyeksi sebelumnya. Analisis semacam ini biasanya dikerjakan oleh konsultan teknis yang biasanya menghitung dengan formulasi yang spesifik. Padahal, jika dilakukan secara mandiri, maka kualitas proyeksi yang dihasilkan sebenarnya tidak terlalu rumit. Selanjutnya nara sumber menyajikan materi proyeksi dengan pendekatan baru yang lebih sederhana dan lebih efektif.

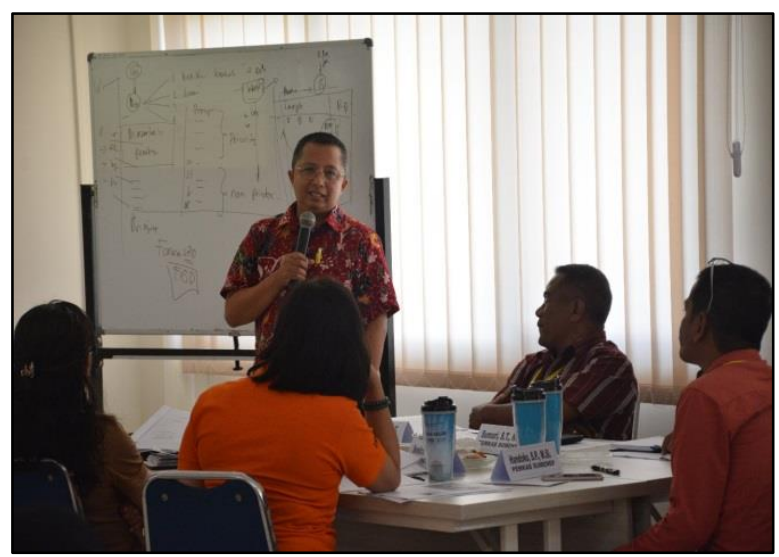

Gambar 2. Evaluasi Pre Test dan Pendalaman Materi

Setelah disampaikan hasil evaluasi pre-test dan penyampaian materi proyeksi dengan metode baru yang dimodifikasi, maka sebagai akhir pelatihan dilakukan post test dengan materi soal yang hampir sama dengan pre-test.

Tabel 4. Data Post-Test Proyeksi

\begin{tabular}{clc}
\hline No & \multicolumn{1}{c}{ ID Peserta } & Hasil \\
\hline 1 & Bappeda 02 & 80 \\
2 & Bappeda 05 & 85 \\
3 & Pemda 01 & 85 \\
4 & Bappeda 06 & 80 \\
5 & Pemda 02 & 60 \\
6 & Dinas 12 & 70 \\
7 & Dinas 13 & 70 \\
8 & Pemda 05 & 60 \\
9 & Pemda 07 & 55 \\
10 & Bappeda 01 & 50 \\
11 & Bappeda 09 & 50 \\
12 & Bappeda 08 & 50 \\
\hline
\end{tabular}




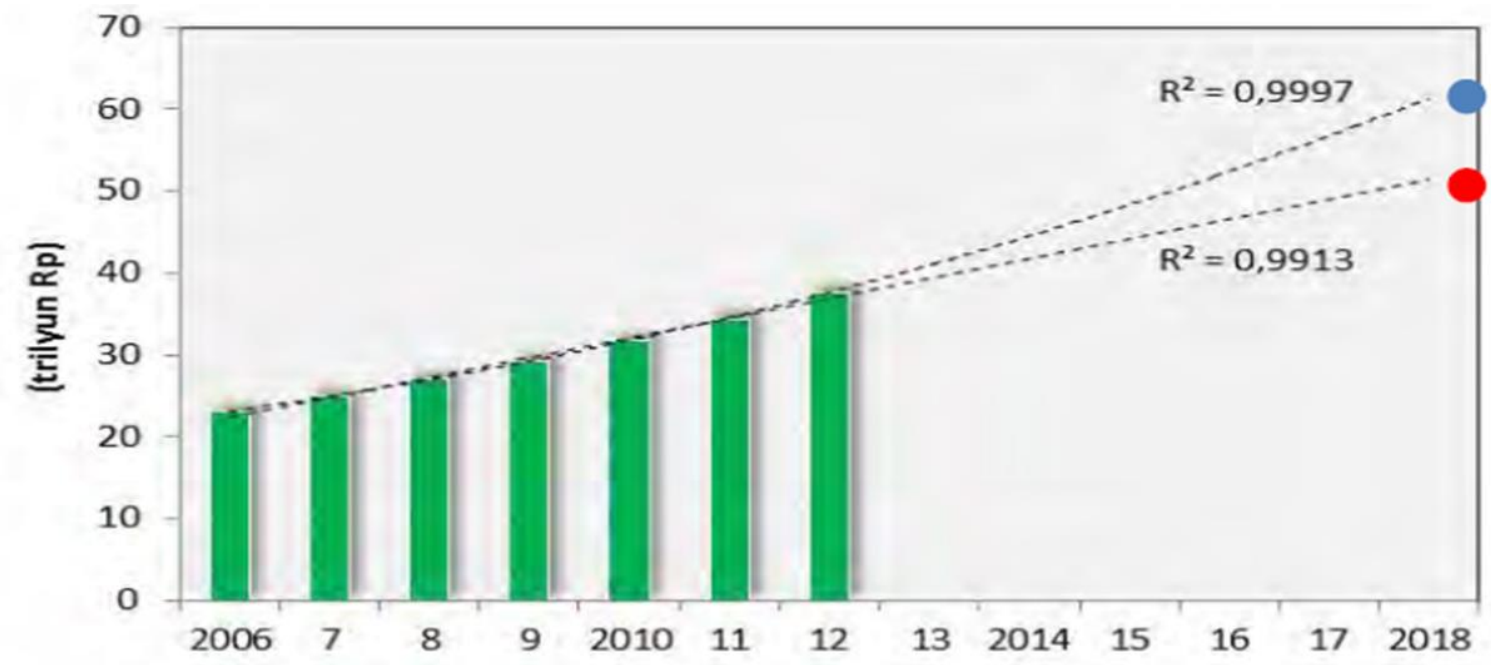

Gambar 3. Visualisasi Proyeksi PDRB dengan Excel

Berbeda dengan pre-test, untuk post ini peserta hanya diberikan jatah alokasi waktu pengerjaan selama 15 menit. Hasil post-test menunjukkan bahwa secara umum terdapat kenaikan poin nilai peserta diklat. Sebanyak $75 \%$ peserta sudah dapat mengerjakan dengan hasil minimal cukup baik (diatas poin 50).

Banyak faktor yang menyebabkan nilai posttest proyeksi ini lebih tinggi. Pertama, peserta sudah mendapatkan strategi pengerjakan soal yang lebih cepat. Kedua, materi soal sebenarnya sudah pernah diperkenalkan sehingga tidak lagi membuat peserta "shock". Ketiga, peserta sudah dibantu untuk mengerjakan soal menggunakan software aplikasi Excel sehingga hasil perhitungan lebih cepat dan akurat.

Dengan bantuan software, peserta diklat bahkan bisa juga membuat visualisasi proyeksi indikator pembangunan (seperti PDRB) secara lebih "profesional". Gambar 3 menyajikan hasil proyeksi PDRB daerah tertentu menggunakan aplikasi Excel. Gambar tersebut sebenarnya hasil croping dari dokumen RPJMD Kota Bandung tahun 2013-2018.

Berbekal contoh serta materi yang disampaikan, banyak peserta yang mencoba mengutak-atik data obyektif masing-masing daerah untuk membuat proyeksi. Hasilnya, banyak peserta yang akhirnya berhasil membuat proyeksi lima tahunan dengan metode sederhana. Data post-test menunjukkan bahwa terdapat 25 persen peserta diklat yang belum dapat mengerjakan tugas dengan cukup baik. Setelah diadakan penelusuran lebih dalam maka dapat diketahui bahwa peserta tersebut memang belum pernah memiliki pengalaman sama sekali dengan alat-alat kuantitatif. Sungguhpun demikian, dengan bantuan software, semua peserta dapat membuat proyeksi. Jenis proyeksi yang dihasilkan tidak hanya berbentuk linear, namun juga berbentuk non-linear.

Meskipun secar teknis, penyusunan proyeksi ini relatif mudah untuk diterapkan, namun ada beberapa catatan penting yang berhasil dirangkum dari hasil diskusi dengan peserta diklat. Pertama, hasil proyeksi tetaplah merupakan estimasi yang perlu dikaji ketepatannya secara kontinyu. Kedua, proyeksi berbasis data historis tidak boleh mengabaikan informasi aktual dan prospek ekonomi ke depan (forward looking). Ketiga, dibutuhkan kualitas data yang dapat digunakan oleh penyusun atau perencana daerah. Data yang berkualitas merupakan kunci dari keberhasilan proyeksi.

Bagian terakhir dari pelatihan adalah mendiskusikan kegunaan proyeksi untuk data yang sifatnya volatile (naik turun) dalam jangka waktu cepat, serta proyeksi yang bersifat kualitatif. Secara teknis, data-data yang sifatnya volatile tidak bisa didekati dengan proyeksi linear. Oleh karena itu diperlukan metode lain guna menghasilkan proyeksi yang lebih halus. Beberapa pendekatan bisa digunakan sebagai alternatif. Berikut disampaikan contoh kasus dimana model simple proyeksi mungkin tidak cukup efektif dalam menghasilkan proyeksi yang tepat.

Kasus 1, proyeksi penduduk akan lebih baik meggunakan model proyeksi logaritmic. Kecenderungan yang terjadi adalah jumlah penduduk mengalami peningkatan namun dengan tambahan yang semakin sedikit. Oleh karena itu model non-linear yang bersifat smoothing jangka panjang akan lebih cocok. 
Kasus 2, perubahan harga barang atau inflasi mungkin lebih cocok menggunakan pendekatan Moving Average (MA). Sifat inflasi yang naik turun dengan ritme yang siklikal cenderung akan sulit diidentifikasi pergerakannya menggunakan proyeksi linear. Akan lebih baik menggunakan info prediksi yang dikeluarkan oleh badan yang lebih kredibel seperti Bank Indonesia.

Kasus 3, proyeksi untuk indikator target tertentu mungkin diperlukan masukan dari para ahli untuk membuat prediksi. Contoh, target penurunan angka kemiskinan mungkin tidak perlu menggunakan data historis kemiskinan yang semakin naik. Kalau itu dilakukan maka tujuan perencanaan bersifat kontraproduktif. Meskipun data aktual, sebagai misal, angka kemiskinan cenderung naikm akan tetapi proyeksi perencanaan tetap harus menghasilkan penurunan angka kemiskinan. Metode historis mungkin tidak dapat digunakan dalam kasus ini.

\section{KESIMPULAN}

Berdasarkan proses diklat yang dilaksanakan, khususnya terkait dengan materi proyeksi data daerah, dapat disimpulkan beberapa hal penting. Pertama, masih relatif banyak aparat perencana daerah yang tidak memiliki kemampuan untuk melakukan proyeksi kuantitatif. Kedua, dengan pelatihan yang memadahi akan semakin banyak aparat yang bisa menggunakan alat untuk membuat proyeksi secara efektif. Jika kecenderungan ini meningkat, maka ke depan ketergantuan badan perencana daerah (Bappeda) terhadap konsultan proyeksi indikator seharusnya mulai berkurang. Ketiga, keberhasilan penyusunan dokumen perencanaan tidak bisa berdiri sendiri tanpa dukungan pihak lain. Kualitas data menjadi unsur penting sehingga nantinya penyusunan rencana berbasis data akan menjadi budaya dalam penyusunan rencana daerah.

Berdasarkan simpulan, maka rekomendasi yang diajukan adalah model pelatihan penyusunan dokumen perencanan masih perlu diintensifkan. Badan perencana daerah yang berhasil membuat dokumen perencanaan dengan bagus selayaknya mendapat insentif yang menarik agar ketergantungan penyusunan dokumen perencanaan pembangunan daerah tidak sepenuhnya bergantung pada konsultan penyusun naskah. Karena sejatinya, tugas perencanaan harus dilakukan oleh aparat perencana.

\section{DAFTAR PUSTAKA}

Adriansyah, A., Firdausi, N., \& Wulan, T. D. 2019. Pengenalan Perencanaan Program Desa Berbasis Bukti: Studi di Desa Murtajih Kecamatan Pademawu Kabupaten Pamekasan. Jurnal Pangabdhi . Vol 5. No 2. 62-67 pp.

Badan Pusat Statistik. 2010. Pedoman Perhitungan Proyeksi dan Angkatan Kerja. Jakarta: Badan Pusat Statistik.

Orbawati, E. B. 2002. Kedudukan Renstra Dalam Proses Perencanaan Pembangunan Daerah. Jurnal Penelitian Inovasi. 34-37 pp.

Putra, K., \& Meydiawati, L. G. 2017. Analisis Vector Auto Regressive Terhadap Kausalitas Inflasi dan Jumlah Uang Beredar Indonesia. E-Journal EP Unud. Vol 4. No 3. 180-189 pp.

Rasyid, M. 2015. Vektor Auto-regresi: Catatan Historis dan Pengembangan. Media Trend. Vol 10. No 1. 57-73 pp.

Saputra, A., Tarno, \& Warsito, B. 2012. Analisis Data Runtut Waktu dengan Metode Adaptive Neuro Fuzzy Inference System (ANFIS). Jurnal Gaussian. 31-40 pp.

Soares, A., Nurpratiwi, R., \& Makmur. 2015. Peranan Pemerintah Daerah Dalam Perencanaan Pembangunan Daerah. Jurnal Ilmu Sosial dan Ilmu Politik. Vol 4. No 2. 231-236 pp. 
30 Jurnal Pangabdhi 